\title{
S5ynthesis
}

International Scientific Conference of IT and Business-Related Research

\section{RAZVOJ PREDUZETNIŠTVA I INDUSTRIJSKE POLITIKE U EVROPSKOJ UNIJI I ZEMLJAMA ZAPADNOG BALKANA}

\author{
ENTREPRENEURSHIP AND INDUSTRIAL POLICY DEVELOPMENT \\ IN THE EUROPEAN UNION AND WESTERN BALKAN COUNTRIES
}

\author{
Sanja Filipović ${ }^{1}$, Lidija Barjaktarović ${ }^{2}$ \\ ${ }^{1}$ Ekonomski institut Beograd, Kralja Milana 16, Beograd, Srbija; \\ ${ }^{2}$ Univerzitet Singidunum, Poslovni fakultet u Beogradu, Danijelova 32, Beograd, Srbija
}

\begin{abstract}
Apstrakt:
Industrijska politika i razvoj preduzetništva u Evropskoj uniji se delimično vodi na nacionalnom, a delimično na nadnacionalnom, odnosno evropskom nivou. Zemlje Zapadnog Balkana kao kandidati za pristupanje Evropskoj uniji u obavezi su da predstave nacionalnu politiku industrije i razvoja preduzetništva, kako bi se procenilo da li su njihove politike u skladu sa principima Evropske unije, posebno u pogledu privatizacije i restrukturiranja. Cilj ovog rada je da se na osnovu analize osnovnih principa Evropske unije kao i analize pomenutih nacionalnih politika zemalja Zapadnog Balkana, utvrdi koji su ključni problemi u razvoju industrijske politike i preduzetništva u zemljama regiona. Posebna pažnja biće posvećena analizi performansi malih i srednjih preduzeća u Srbiji kao i definisanja prateće politike.
\end{abstract}

\section{Ključne reči:}

industrijska politika, preduzetništvo, EU, Zapadni Balkan.

\begin{abstract}
:
Industrial policy and entrepreneurship development in the European Union is partly led on national and supranational level, i.e. European level. Western Balkan countries, as candidates for membership in the European Union, are obliged to present national policy of industry and entrepreneurial development, in order to determine their compatibility with the principles of the European Union in terms of privatization and restructuring. The aim of this research is to determine the key problems in development of industrial policy and entrepreneurship in Western Balkan economies on the basis of the analysis of the main principles of the European Union and defined policies in those countries. Special attention shall be devoted to the analysis of performances of small and medium-sized enterprises in Serbia and defining of the accompanying policies.
\end{abstract}

\section{Key words:}

industrial policy, entrepreneurship, EU, Western Balkan.

\section{Zahvalnica}

Ovaj istraživački rad deo je projekta br. 47009 „Evropske integracije $i$ društveno-ekonomske promene privrede Srbije na putu ka EU” kao i projekta br. 47028 „Unapređenje konkurentnosti Srbije u procesu pridruživanja EU”, u periodu 2011-2015, koji su finansirani od starne Ministarstva nauke i tehnološkog razvoja Republike Srbije.

\section{UVOD}

Potreba za kreiranjem jedinstvene industrijske politike na teritoriji današnje Evropske unije (EU) datira još iz perioda formiranja Carinske unije i zajedničkog tržišta. Prvi dokument u kome su definisani principi i ciljevi zajedničke industrijske politike tadašnje Evropske ekonomske zajednice bio je „Industrijska politika Zajednice” (COM (70)100), koji je usvojen 1970. godine. Cilj industrijske politike bio je da se obezbedi organizacija zajedničkog tržišta, izvrši restrukturiranje preduzeća, usaglašavanje pravnog, poreskog i finansijskog zakonodavstva.

Početkom 1980-ih godina industrijska politika je bila uglavnom usmerena na restrukturiranje pojedinih industrijskih sektora koji su se našli u problemu usled neslaganja zemalja članica u tada još uvek nedovoljno homogenom tržišnom okruženju Evropske ekonomske zajednice. Tek nakon usvajanja Akta o jedinstvenoj Evropi iz 1987. godine, industrijska politika postaje proaktivnija i orijentiše se ka visokoj tehnologiji (Sauter, 1997). Stoga se može reći da se razvoj industrijske politike Evropske ekonomske zajednice kretao od sektorskog protekcionizma ka horizonatalnoj podršci i promociji konkurentnosti (Mićić, 2008).
Početkom 1990-tih godina prešlo se na horizontalni pristup i definisanje koordinirane nadnacionalne industrijske politike EU. Veliki doprinos tome bilo je uvođenje industrijske konkurentnosti u Sporazumu u Mastrihtu (1992) i usvajanje Lisabosnke strategije (2000). Nova etapa u vođenju industrijske politike je zvanično započela Lisabonskim samitom Evropskog saveta 2000. godine kada je postavljen strateški cilj da EU do 2010. godine postane najkonkurentnija i najdinamičnija privreda sveta, zasnovana na znanju i sposobna da ostvari održivi ekonomski rast, veću zaposlenost i socijalnu koheziju.

Tokom 2000. godine ključni pravac razvoja bio je usmeren ka izgradnji konkurentnosti. Počev od 2003. godine kada je usvojen je dokment „Ključna pitanja vezana za konkurentnost Evropskog tržišta - ka intergisanom pristupu" (COM(2003) 704), kojim je definisano nekoliko komunikacija. Tokom 2005. godine učinjen je pomak usvajanjem nove komunikacije „Saopštenje o sprovođenju Lisabonskog programa Zajednice: okvir praktične politike za jačanje prerađivačke industrije u EU - ka integrisanijem pristupu industrijskoj politici COM(2005) 474", kojom je dat podsticaj za stvaranje još jedinstvenije industrijske politike, odnosno bolje klime za razvoj svih industrijskih sektora. Tako definisana industrijska politika predstavljala je stub implementacije i rea- 
lizacije ambicioznih ciljeva Lisabonske strategije. Nakon toga usvojeno je nekoliko dokumenata ${ }^{1}$ koji su predstavljali reviziju pomenute strategije.

Sledeći bitan dokument koji predstavlja osnovu aktuelne industrijske politike EU jeste usvajanje Evropa 2020: „Strategija za pametni, održivi i inkluzivni rast”. U skladu sa ciljevima Strategije 2020 (EPuS, 2015), Evropska komisija je 2010. godine usvojila dve komunikacije (EC, 2010b; EC, 2010c) koje industriju vide kao ključni preduslov ukoliko se želi da Evropska unija postane globalni ekonomski lider. Nakon toga usledilo je usvajanje dokumenta „Industrijska politika: jačanje konkurentnosti” (COM(2011)0642) koja kao i prethodna dokumenta stavlja naglasak na razvoj konkurentnosti, ali pre svega kao neophodnost oporavka industrije EU u uslovima ekonomske krize.

U cilju oporavka industrije i rasta njenog učešća u bruto domaćem proizvodu, Evropska komisija je 2012. godine usvojila Saopštenje o industrijskoj politici („Saopštenje Evropske komisije o industrijskoj politici: Jača Evropska industrija za rast gospodarski oporavak", EC, 2012). Kao glavni stubovi razvoja industrijske politike definisani su: rast investicija u inovacije, bolji uslovi poslovanja, pristup finansijama i kapitalu, unapređenje humanog kapitala i veština.

Zemlje Zapadnog Balkana (Albanija, Bosna i Hercegovina, Crna Gora, Makedonija, Kosovo i Srbija) kao kandidati za članstvo u EU su u obavezi da poštuju pravne tekovine EU i da izvrše usaglašavanje nacionalnog regulatornog okvira. Posmatrano sa pravne tačke gledišta, oblast industrijske politike i preduzetništva nije tehnički zahtevna u smislu da se izuzev Direktive 2011/7/EU sve pravne tekovine nalaze u formi saopštenja i preporuka. U poslednjih nekoliko godina u zemljama Zapadnog Balkana učinjen je znatan pomak u pravcu unapređenja zakonodavnog okvira, pre svega u oblasti unapređenja investicione klime. Strategiju industrijske politike do sada su usvojile jedino Srbija i Makedonija, dok je Crna Gora započela proces izrade strategije krajem 2014. godine. Srbija je krajem marta 2015. godine usvojila i novu Starategiju za podršku razvoju MSP, preduzetništva i konkurentnosti za period 2015-2020 sa pratećim akcionim planom.

Cilj ovog rada je da se, na osnovu analize osnovnih principa EU kao i analize pomenutih nacionalnih politika zemalja Zapadnog Balkana, utvrdi koji su ključni problemi u razvoju industrijske politike i preduzetništva u zemljama regiona. Posebna pažnja biće posvećena analizi performansi malih i srednjih preduzeća u Srbiji kao i analizi pratećih strateških dokumenata. Pored uvodnog dela i zaključnih razmatranja, rad je struktuiran tako da prati analizu razvoja industrijske politike i preduzetništva na nivou EU, zemalja Zapadnog Balkana i Srbije.

\section{INDUSTRIJSKA POLITIKA I RAZVOJ PREDUZETNIŠTVA U EVROPSKOJ UNIJI}

Pravne tekovine EU koje se odnose na preduzetništvo i industrijsku politiku su definisane u poglavlju 20, a nadležan za ovu oblast je Generalni direktorat za unutrašnje tržište, industriju, preduzetništvo i mala i srednja preduzeća Evropske komisije. Pravne tekovine u okviru ovog poglavlja u najvećem delu se sastoje od načela politike i instrumenata koji su sadržani u saopštenjima, preporukama i zaključcima Saveta i nije ih potrebno direktno prenositi u domaće zakonodavstvo. Izuzetak predstavlja Direktiva 2011/7/EU o borbi protiv zakasnelog plaćanja u komercijalnim transakcijama (Directive 2011/7/

1 Sve usvojene komunikacijeEvropske komisije u periodu nakon 2000. godine dostupne su na:

http://ec.europa.eu/enterprise/policies/industrial-competitiveness/ documents/index_en.htm
EU on combating late payment in commercial transactions) i Preporuka Evropske komisije u vezi definisanja mikro, malih i srednjih preduzeća. Politika EU u oblasti malih i srednjih preduzeća (MSP) obuhvaćena je Aktom o malim preduzećima za Evropu (Small Business Act for Europe, SBA), gde se između ostalog insistira na primeni zajedničke definicije malih i srednjih preduzeća.

Aktuelna industrijska politika EU definisana je Communication on Industrial policy "For a European Industrial Renaissance" (EC, 2014) koji je Evropska komisija usvojila u januaru 2014. godine. Ključna poruka ovog strateškog dokumenta je da EU treba da definiše novu podlogu za oporavak od ekonomske krize, a industrija u tom procesu treba da ima ključnu ulogu s obzirom na značaj koji ima u kreiranju radnih mesta i ostvarivanju ekonomskog rasta. U prilog tome ide činjenica da industrijski sektor zapošljava četvrtinu svih zaposlenih u privatnom sektoru, a svako radno mesto u industrijskoj proizvodnji stvara 2 do 3 nova radna mesta u uslugama. Čak $80 \%$ istraživanja i inovacija je registrovano $u$ industrijskom sektoru (Rueda-Cantuche et al., 2012). Prema podacima Eurostata, industrijski proizvodi čine $80 \%$ ukupnog izvoza EU i na osnovu trgovine industrijskim proizvodima se ostvaruje suficit od 365 milijardi evra (EUR). Uglavnom se radi o industrijskim proizvodima visoke i srednje tehnologije (autoindustrija, mašinska industrija i oprema, farmaceutski i hemijski proizvodi, itd.). MSP predstavljaju 99\% svih preduzeća EU, odnosno oko 21 milion preduzeća. Ova kategorija preduzeća zapošljava 133 miliona radno aktivnih i ključni su izvor preduzetničkog duha i inovacija, koji su presudni za konkurentnost preduzeća u EU. Cilj politike EU na području preduzetništva je da se politike i mere prilagode malim preduzećima i tako doprinesu atraktivnosti Evrope za osnivanje preduzeća i poslova (Filipović, 2014).

U istoj komunikaciji Evropska komisija ukazuje na značaj pune i efektivne primene industrijske politike i podstiče stvaranje inovativnog okruženja povoljnog za: pokretanje novih i unapređenje starih poslova, rast domaćih i stranih investicija, osnivanje i razvoj MSP i preduzetništva (MSPP), primenu modernih tehnologija (nanotehnologija, mikro/nanoelektronike, industrijske biotehnologije, naprednih materijala i/ili fotonike, proizvodnje pomoću naprednih tehnologija). U cilju unapređenja konkurentnosti industrije, Evropska komisija navodi sledeće ključne prioritete:

1. neophodno je jačati konkurentnost i u drugim oblastima privrede (npr. rast produktivnosti u poslovnim uslugama),

2. maksimalno uvećati potencijale unutrašnjeg tržišta razvijanjem infrastrukture, dalje integrisanje tržišta kapitala, poboljšanje mogućnosti za obuku i mobilnost građana na unutrašnjem tržištu rada,

3. sprovođenje instrumenata regionalnog razvoja sa nacionalnim i EU instrumentima za podršku inovacija, razvoj veština i preduzetništva,

4. obezbediti pristup kritičnim inputima (posebno energiji i sirovinama) po povoljnim cenama koje odražavaju međunarodne uslove troškova,

5. uključivanje kompanija iz EU u globalne lance vrednosti kako bi povećale svoju konkurentnost i obezbedile pristup globalnim tržištima sa povoljnijim konkurentnim uslovima,

6. reindustrijalizacija treba da obezbedi rast učešća industrije u bruto domaćem proizvodu od $20 \%$ do 2020 .

Nekadašnje razlike između industrijske proizvodnje i usluga sve se više smanjuju tako da oba sektora imaju interaktivnu ulogu u stvaranju nacionalne konkurentnosti. EU sve više naglašava celoviti i horizontalni pristup industrijskoj strategiji koji uzima u obzir horizontalne (sektorski nediskriminativne) pod- 
sticaje. Buduće smernice industrijske politike idu u pravcu razvoja konkurentnosti, stvaranja povoljnog poslovnog okruženja u cilju podsticanja investicija, kao i kontinuiranog unapređenja preduzetništva i inovacija.

Akt o malim preduzećima predstavlja važeći okvir politike razvoja malih i srednjih preduzeća i preduzetništva $(\mathrm{MSPP})^{2} \mathrm{u}$ EU. SBA je usvojio Evropski savet na samitu u decembru 2008. godine i ovaj dokument je tada zamenio Evropsku povelju o malim preduzećima, koja je od 2000. godine pružala smernice za razvoj ove oblasti, kako na nivou EU, tako i u državama članicama. ${ }^{3}$ Princip na kom počiva SBA je „Misliti prvo o malima“ („Think small first") koji treba da obezbedi da se u svim elementima vođenja ekonomske politike prvo polazi od potreba MSP i efekata koje će novi propisi ili mere imati na njih.

SBA se zasniva na 10 principa, kroz koje su date smernice za kreiranje i sprovođenje politika na nivou EU i zemalja članica. Ovi principi odnose se na stvaranje podsticajnog okruženja u kome se preduzetništvo i porodični biznis vrednuju; pružanje mogućnosti za „drugu šansu“ poštenim preduzetnicima koji su bankrotirali; stvaranje pravila i propisa u skladu sa principom „misliti prvo o malima“; stvaranje javne administracije koja više reaguje na potrebe MSP; olakšavanje učešća MSP u javnim nabavkama i bolje korišćenje državne pomoći; olakšavanje pristupa MSP izvorima finansiranja i stvaranje uslova za blagovremeno izmirivanje dugovanja; pomoć MSP kako bi bolje iskoristili mogućnosti zajedničkog tržišta; unapređenje veština i znanja, inovacije, eko-inovacije i izlazak MSP na rastuća tržišta (posebno Kine i Indije).

Za sve principe razrađeni su predlozi konkretnih mera i aktivnosti, podeljenih na obaveze Evropske komisije i preporuke za zemlje članice, uključujući i četiri predloga novih propisa. Iako ima mnogo zajedničkih elemenata sa Evropskom poveljom o malim preduzećima, SBA predstavlja kvalitativno drugačiji dokument, a uvodi i neke nove prioritete, kao što su podrška eko-inovacijama i „druga šansa“.

Za praćenje sprovođenja SBA Evropska komisija, između ostalih, koristi i alat „SBA Performance review“ (Sagledavanje performansi MSP) koji pruža godišnje informacije o MSP u državama članicama EU i u 9 „partnerskih zemalja“ i sastoji se od Godišnjeg izveštaja o evropskim MSP i od Pregleda informacija o sprovođenju SBA po zemljama (SBA country fact sheets), što je predmet analize narednog poglavlja. ${ }^{4} \mathrm{Na}$ osnovu ovih godišnjih izveštaja, Evropska komisija je pokrenula i proces revizije SBA, koji je okončan u februaru 2011. godine, nakon opsežnih konsultacija sa zainteresovanim stranama. Tom prilikom su se izdvojila četiri prioriteta SBA:

1. unapređenje poslovnog okruženja,

2. bolji pristup finansijama za MSP,

3. unapređenje pristupa novim tržištima i

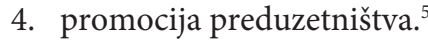

Sa ciljem da se prikupe informacije i ideje o tome na koji način bi se kroz SBA u narednom periodu (2015-2020) nastavila politika podrške MSP, Evropska komisija je u septembru 2014. godine pokrenula novi proces konsultacija. Konsultacije su završene u decembru 2014. godine, te nas u narednom periodu očekuje i novi dokument u oblasti politike razvoja MSP.

2 Ovim terminom suobuhvaćena mikro, mala i srednja pravna lica, kao i preduzetničke radnje.

3 Izvor: http://ec.europa.eu/growth/smes/business-friendly-environment/small-business-act/index_en.htm

$4 \mathrm{http} / /$ /ec.europa.eu/growth/smes/business-friendly-environment/ performance-review/index_en.htm

5 Communication from the Commission to the European Parliament, the Council, Economic and Social Committee and the Committee of the Regions, Review of the "Small Business Act" for Europe, $\operatorname{COM}(2011) 78$ final

\section{RAZVOJ INDUSTRIJSKE POLITIKE I PREDUZETNIŠTVA U ZEMLJAMA ZAPADNOG BALKANA}

Struktura sektora MSP u zemljama Zapadnog Balkana je slična strukturi Evropske unije. Broj registrovanih mikro preduzeća (manje od 10 zaposlenih, uključijući same preduzetnike) je vrlo visok (u rasponu od 88,9\% u Crnoj Gori do 95,9\% u Srbiji), ali je njihov doprisnos nivou zaposlenosti i kreiranju dodate vrednosti vrlo nizak, reflektujući nizak nivo produktivnosti po zaposlenom u poređenu sa MSP.

MSP preduzeća kreiraju najveću dodatu vrednost u zemljama Zapadnog Balkana, dok privatni sektor zapošljava od $61 \%$ do $81 \%$ svih zaposlenih u pojedinačnim zemljama. U vreme krize, mnoge države su uvele posebne mere kako bi zaštitile sektor MSP, kao što su restrukturiranje bankarskih kredita i pospešivanje prodaje u zemlji i inostranstvu.

U skladu sa SBA, MSPP politika se sastoji u kombinovanju horizontalnih i targetiranih politika. Horizontalna politika definiše aktivnosti u vezi operativnog okruženja preduzetnika, kao što su pojednostavljenje zakonskih procedura i unapređenje regulatornog okvira za finansiranje. Targetirane mere imaju za cilj određene segmente preduzetnika, kao što su inovativni, početnici (start-up) ili izvozno orijentisani preduzetnici. Mere vlade su primarno usmerene na unapređenje opšteg poslovnog ambijenta i koordinaciju tržišnih uslova za određene (targetirane) grupe preduzetnika.

Zemlje Zapadnog Balkana beleže napredak u nekoliko oblasti, uključujući institucionalni okvir za politiku MSPP, regulatorne reforme i pojednostavljene administrativne procedure, obrazovanje preduzetnika, kao i pravni okvir za obezbeđenje povoljnijeg finansiranja. Takođe, imaju rezultate u razvoju preduzetničkih veština i promociji izvoza. Međutim, uspešnost u naplati realizovanih usluga i proizvoda je problematična. Novi izazov je razvoj okvira za podsticanje ženskog preduzetnišva.

Trebalo bi imati u vidu da je nivo napretka različit u pojedinačnim zemljama ovog regiona, što zbog dostignutog ekonomskog razvoja, što zbog različitog stepena napretka u pridruživanju EU.

Srbija je imala dobar progres u različitim dimenzijama razvojne politike. Takođe, sprovela je značajne elemente MSPP politike kroz visoku regionalizaciju. To je podstaklo redizajniranje osnovnog alata MSPP politike - načina finansiranja preduzeća (kao što je spajanje Fonda za razvoj i Garantnog fonda Republike Srbije) i unapređenje primene mera za podršku inovacijama. Dodatno, uspostavljena je strategija i ostvaren je partnerski odnos u obrazovanju preduzetnika.

BJR Makedonija, Crna Gora i Albanija su ostvarile zadovoljavajući nivo konvergencije u upravljanju MSPP politikom, ali je njihova primena daleko od predviđenih okvira. Sve tri zemlje imaju zadovoljavajući nivo MSPP politike u domenu osnivanja preduzeća, regulatornih reformi i pristupu finansiranju. Međutim, nizak je nivo u implementaciji željene politike i merama za podršku inovacija u MSPP.

Bosna i Hercegovina, i Kosovo su ispod regionalnog proseka u najvećem broju dimenzija MSPP politike, uključujući i ograničeni nivo konvergencije upravljanja i sprovođenja politike MSP. Ipak, od 2009.godine, obe zemlje imaju minimalni napredak u oblasti obrazovanja i razvoja veština kod preduzetnika.

Grafikonom 1 su prikazani rezultati SBA indeksa za zemlje Zapadnog Balkana. Procena je bazirana na pomenutih deset osnovnih principa SBA, koji su dalje razgranati na 12 relevantnih dimenzija politike sa 108 indikatora. Indikator ima vrednosti: status quo i/ili progres u razvoju politike u rasponu od 1 
(nisko) do 5 (visoko). Ovi rezultati su agregirani u zavisnosti od dimenzije politike kao ponderisani prosek računat u skladu sa relativnim zančajem svakog indikatora.

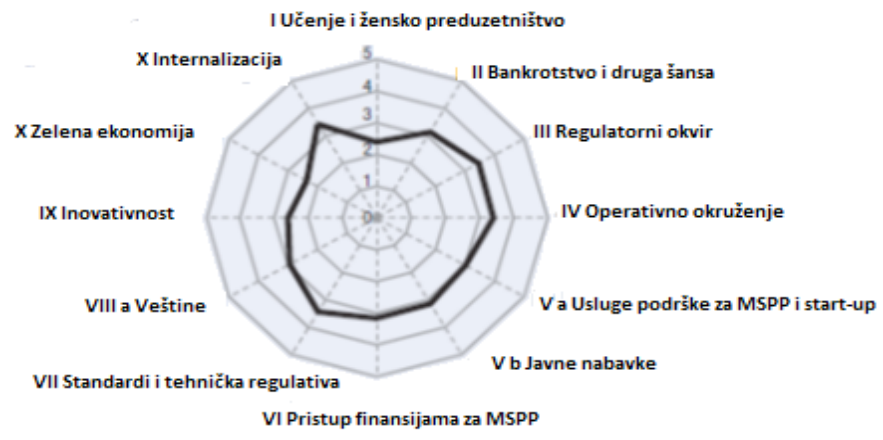

Grafikon 1. Rezultati SBA indeksa za zemlje Zapadnog Balkana

\section{ANALIZA STANJA MSSP SEKTORA U SRBIJI I RELEVANTNE POLITIKE}

\subsection{SEKTOR MSPP U SRBIJI}

Prema poslednjem Izveštaju o MSPP iz decembra 2014. godine, broj MSPP u Srbiji je 315.412, što čini 99,8\% ukupno aktivnih preduzeća. MSPP zapošljavaju blizu 2/3 zaposlenih u nefinansijskom sektoru, čine 64,3\% ukupnog prometa i učestvuju sa oko 30\% u formiranju bruto domaćeg proizvoda (BDP). MSPP u ukupnom broju izvoznika učestvuju sa $98 \%$, ali izvoze svega $43 \%$ nefinansijskog sektora, što znači da su najveći izvoznici velika preduzeća. U strukturi sektora MSPP najbrojnija su mikro preduzeća (303.927), dok MSP (11.485) dominiraju po svim posmatranim pokazateljima (53,6\% zaposlenosti, $60,9 \%$ prometa, $60,8 \%$ bruto dodate vrednosti , 75,2\% izvoza, 76,1\% uvoza MSPP). Međutim, visoko učešće sektora MSPP u osnovnim pokazateljima poslovanja privrede, rezultat je usporene dinamike sprovođenja ukupnih strukturnih reformi, a ne visokog nivoa razvijenosti i konkurentnosti MSPP. U tabeli 1. prikazani su osnovni pokazatelji sektora MSPP Srbije u poređenju sa izabranim zemljama EU i prosekom EU-28.

Ukoliko se analizira sektor MSPP u poslednjih nekoliko godina, evidentan je retrogradni uticaj globalne ekonomske krize. Tako je u odnosu na 2007. godinu zabeležen pad prome- ta sektora MSPP od 16,3\%, pad bruto dodate vrednosti (BDV) $19,5 \%$ i profita od $28,1 \%$. S druge strane, velika preduzeća su u odnosu na 2007. godinu ostvarila rast profita od 13,5\%, dok je opao promet za $2,5 \%$ i BDV za $5 \%$. Na grafikonu 2. prikazan je trend kretanja osnovnih pokazatelja poslovanja MSPP (puna linija) i velikih preduzeća (isprekidane linije) za period 20072013. godine.

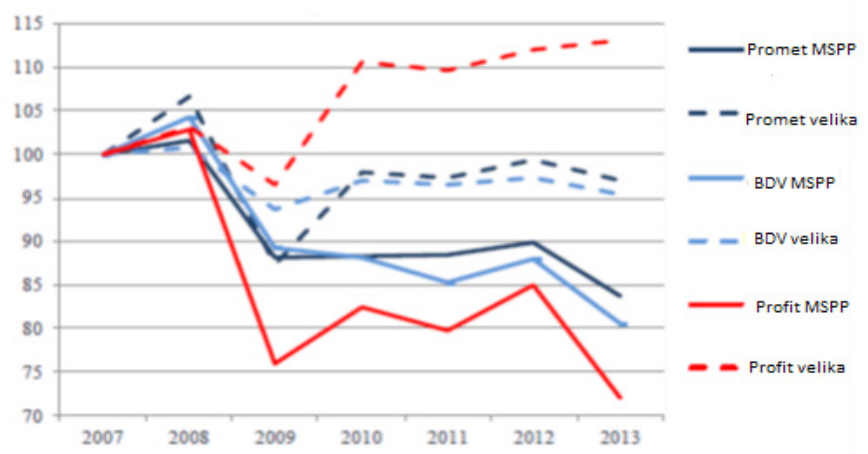

Grafikon 2. Efikasnost poslovanja MSPP sektora Srbije, bazni indeks $2007=100$

Izvor: Izveštaj o MSPP, Ministarstvo privrede, 2014.

Od početka krize zaposlenost u sektoru MSPP se konstantno smanjuje, s tim da je najveći godišnji pad zaposlenosti zabeležen 2009. godine (-7,2\%). Za razliku od sektora MSPP, velika preduzeća su povećala zaposlenost u 2011. i 2012. godini, ali nedovoljno da bi se smanjio ukupan rast nezaposlenosti u privredi. U 2013. godini, dolazi do opšteg pada broja zaposlenih u svim preduzećima nefinansijskog sektora. Na grafikonu 3. dat je uporedni pregled trenda zaposlenosti u apsolutnim iznosima i kao procenat promene u odnosu na prethodnu godinu.

\subsection{INDUSTRIJSKA POLITIKA I RAZVOJ PREDUZETNIŠTVA U SRBIJI}

Kreiranje i sprovođenje industrijske politike i politike razvoja MSP u Srbiji je u nadležnosti Ministarstva privrede. Osnovni nacionalni strateški dokumenti u ovoj oblasti su Strategija i politika razvoja industrije RS od 2011. do 2020. (Sl. glasnik RS, 55/11) i Strategija za podršku razvoju malih i srednjih preduzeća, preduzetništva i konkurentnosti za period 2015-2020. sa pratećim Akcionim planom koja je usvojena krajem marta 2015. godine.

\begin{tabular}{|c|c|c|c|c|c|c|c|}
\hline & Srbija & EU-28 & Bugarska & Češka & Mađarska & Slovenija & Poljska \\
\hline Broj preduzeća & 315,4 & 20614 & 314 & 948,3 & 570 & 106,5 & 1391 \\
\hline Br. zaposlenih & 768 & 87092 & 1474 & 2376,8 & 1809 & 413,9 & 5494 \\
\hline BDV, mlrd EUR & 8,5 & 3430 & 12,1 & 47,9 & 26,6 & 11,9 & 89,8 \\
\hline MSP na hilj. stanovnika & 44,1 & 41 & 43,1 & 90,2 & 57,5 & 51,7 & 36,1 \\
\hline Zaposleni po preduzeću & 2,4 & 4,2 & 4,7 & 2,5 & 3,2 & 3,9 & 3,9 \\
\hline BDV po zaposlenom & 11,1 & 39,4 & 8,2 & 20,2 & 14,7 & 28,8 & 16,3 \\
\hline \multicolumn{7}{|c|}{ Procentualno učešće MSP u nefinansijskom sektoru } \\
\hline Br. preduzeća & 99,8 & 99,8 & 99,8 & 99,9 & \multicolumn{4}{|c|}{99,9} & 99,8 & 99,8 \\
\hline Br. zaposlenih & 64,9 & 66,7 & 75,9 & 69,7 & 73,0 & 70,3 & 68,1 \\
\hline BDV & 54,1 & 57,8 & 61,9 & 55,5 & 53,8 & 62,7 & 51,8 \\
\hline
\end{tabular}

Tabela 1. Komparacija osnovnih pokazatelja poslovanja MSPP sektora Srbije u odnosu na izabrane zemlje EU, u hiljadama Izvor: Izveštaj o MSPP, Ministarstvo privrede, 2014. 
Zaposlenost u hiljadama

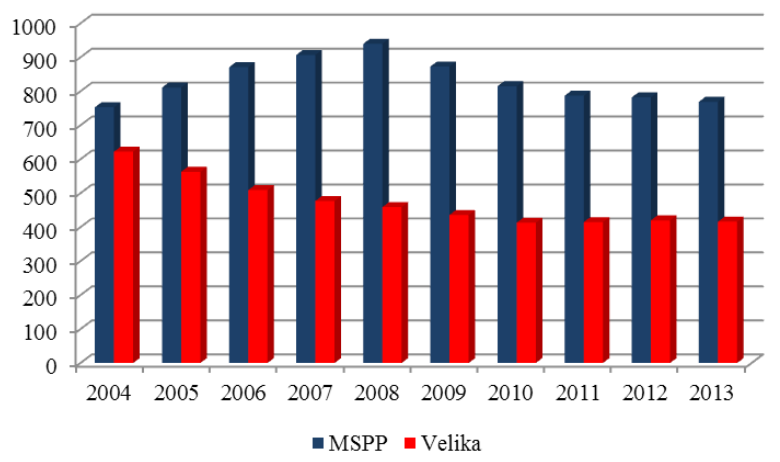

Godišnje stope rasta u \%

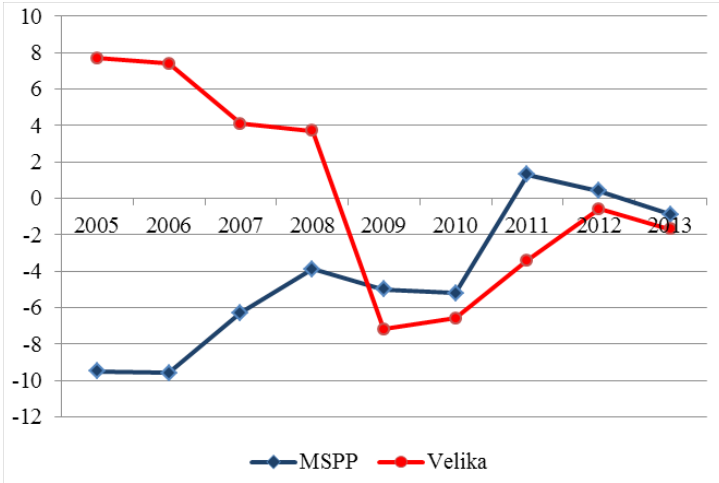

Grafikon 3. Kretanje zaposlenosti u periodu 2007-2013

Izvor: Izveštaj o MSPP, Ministarstvo privrede, 2014.

Strategija i politika razvoja industrije RS od 2011. do 2020. godine je usvojena 2011. godine i predstavlja prvi razvojni dokument koji na konzistentan i celovit način definiše osnovne razvojne prioritete industrije i načine njihovog ostvarivanja. Strategija ima horizontalni pristup, ali daje poseban naglasak na sektorima koji stvaraju visoku dodatu vrednost (industrija hrane, industrija saobraćajnih sredstava, informaciono-komunikaciona tehnologija, metalski kompleks i farmaceutska industrija). U Strategiji su kvantitativno i kvalitativno definisani svi ciljevi, koji su dalje operacionalizovani u Akcionom planu putem tri osnovne vrste mera:

1. opšte mere i instrumenti ekonomske politike u funkciji pravne sigurnosti, predvidivosti i transparentnosti primene zakona i drugih relevantnih pravila;

2. permanentno smanjivanje svih barijera koje ometaju poslovanje;

3. intenzivna podrška svim privrednim društvima koja svoje aktivnosti preusmeravaju na novu proizvodnju, izvoz, primenu novih znanja i jačanje novih tehnologija i inovativnosti.

Starategija za podršku razvoju MSP, preduzetništva i konkurentnosti za period 2015-2020. sa pratećim Akcionim planom ${ }^{6}$ predstavlja sastavni deo strateškog okvira za razvoj konkurentnosti Srbije i komplementaran je sa ranije usvojenim dokumentima u ovoj oblasti (Strategijom i politikom industrijskog razvoja 2011-2020.), odnosno treba da zameni Strategiju razvoja konkurentnih i inovativnih malih i srednjih preduzeća 2008-2013. godine. Nova Starategija predstavlja okvir mera za unapređenje preduzetništva i konkurentnosti u narednom srednjoročnom periodu, koji je razrađen u okviru šest stubova: unapređenje poslovnog okruženja, unapređenje pristupa izvorima finansiranja, kontinuirani razvoj ljudskih resursa, jačanje održivosti i konkurentnosti MSP, unapređenje pristupa novim tržištima i razvoj i promocija preduzetničkog duha i podsticanje preduzetništva žena, mladih i socijalnog preduzetništva. Sprovođenje Strategije zasnivaće se na dvogodišnjim akcionim planovima, koji će se pripremati u saradnji sa svim resorno nadležnim državnim institucijama i kroz dijalog sa privatnim sektorom. Stoga je inicirano osnivanje Saveta za MSP, preduzetništvo i konkurentnost kao novog tela koje treba da koordinira aktivnostima u sprovođenju Akcionog plana.

Srbija je bila uključena u proces praćenja primene SBA na nivou EU kroz učešće u procesu sagledavanje performansi MSP (SME Performance Review). U okviru ovog procesa, izrađeni su

6 Nacrt Strategije je dostupan na:

http://www.privreda.gov.rs/UserFiles/File/1_PRIVREDA/Nacrt-

strategije-preduzetnistvo-konkurentnost-9_6_2014.pdf nacionalni izveštaji o primeni SBA za period 2008-2014. godi$\mathrm{nu}^{7}$ (SBA Fact Sheets), koji se zasnivaju na kvantitativnim indikatorima i navođenju najvažnijih rezultata po dimenzijama SBA. ${ }^{8}$ Pored učešća u procesu primene SBA na nivou EU, Srbija učestvuje i u procesu praćenja SBA na regionalnom nivou kroz instrument koji je razvio OECD i Evropska komisija - „Indeks politike MSP“ (SME Policy Index) o čemu je pisano u prethodnom poglavlju. ${ }^{9}$ Poslednji ciklus ocenjivanja u sklopu ovog procesa završen je 2012. godine, dok se početak narednog očekuje u 2015. godini.

Najvažniji instrument u oblasti podrške razvoju preduzetništva i inovativnosti je COSME program, ali Srbija još uvek nije obezbedila sredstva za učešće u ovom programu. U toku je tehničko usaglašavanje odredbi sporazuma o učešću Srbije, što je jedan od elemenata za pisanje Izveštaja o analitičkom pregledu koji Evropska komisija još uvek nije dostavila (Kancelarija za EU integracije, 2014).

U izveštaju Evropske komisije o napretku Srbije za 2014. godinu konstatovano je da Srbija treba da nastavi da se zalaže za poboljšanje poslovnog okruženja, a jedan od prioriteta je usvajanje novog zakona kojim bi se olakšalo izdavanje građevinskih dozvola. Pored toga, ocenjeno je da je proces giljotine propisa u zastoju, da su parafiskalne takse za poslovanje privrednih društava porasle, kao i da je potrebno dodatno zalaganje da se poboljša pristup finansijskim sredstvima za privredna društva. Uzimajući u obzir nizak rang Srbije u zvaničnim izveštajima međunarodnih institucija koje se bave metodologijama praćenja konkurentnosti privrede i poslovnog okruženja (Svetski ekonomski forum, Svetska banka, Savet stranih investitora), to je povod da dalje aktivnosti budu usmerene u pravcu unapređenja uslova poslovanja.

\section{ZAKLJUČAK}

Aktuelna industrijska politika EU je horizontalnog karaktera i bazira se na razvoju konkurentnosti, stvaranja povoljnog poslovnog okruženja u cilju podsticanja investicija, kontinuiranog unapređenja preduzetništva i inovacija. Pravne tekovine EU u najvećem delu se sastoje od načela politike i instrumenata koji

7 Dalje učešće Srbije u procesu praćenja primene SBA na nivou EU zavisi od pristupanja programu COSME, s obzirom da se ovaj proces finansira iz sredstava programa.

8 Poslednja dva izveštaja su dostupna na sledećoj internet adresi: $\mathrm{http} / /$ ec.europa.eu/growth/smes/business-friendly-environment/ performance-review/index_en.htm

9 Više na: http://www.oecd.org/investment/psd/smallandmedium-sizedenterprisessmepolicyindex.htm 
su sadržani u saopštenjima, preporukama i zaključcima Saveta i nije ih potrebno direktno prenositi u domaće zakonodavstvo. Izuzetak predstavlja Direktiva 2011/7/EU o borbi protiv zakasnelog plaćanja u komercijalnim transakcijama i preporuka Evropske komisije u vezi definisanja mikro, malih i srednjih preduzeća u okviru Akta o malim preduzećima.

Zemlje Zapadnog Balkana beleže napredak u nekoliko oblasti, uključujući institucionalni okvir za politiku MSPP, regulatorne reforme i pojednostavljene administrativne procedure, osnivanje kompanije, obrazovanje preduzetnika, kao i pravni okvir za obezbeđenje povoljnijeg finansiranja. Takođe, imaju rezultate u razvoju preduzetničkih veština i promociji izvoza. Međutim, uspešnost u naplati realizovanih usluga i proizvoda je malo niža. Novi izazov je razvoj okvira za podsticanje ženskog preduzetnišva. Trebalo bi imati u vidu da je nivo napretka različit u pojedinačnim zemljama ovog regiona, što zbog dostignutog ekonomskog razvoja, što zbog različitog stepena napretka u pridruživanju EU.

Srbija formalno pravno poštuje pravne tekovine EU i usvojila je strateška dokumenta u ovoj oblasti, ali problem predstavlja njihova implementacija i kontinuirano praćenje i ocena sprovođenja definisanih strateških ciljeva. Ovo je naročito značajno u svetlu novog ciklusa ocene primene SBA na Zapadnom Balkanu i Turskoj u okviru "SME policy index-a", koji počinje 2015. godine, a u okviru kog je OECD najavio da će se pored dosadašnje ocene postojanja politika, institucija i instrumenata podrške, ocenjivati i mehanizmi monitoringa i evaluacije kako politika, tako i pojedinačnih mera i instrumenata. S obzirom na skromne rezultate učešća domaćih institucija i privrednih subjekata u programima EU namenjenih razvoju preduzetništva i inovacija neophodno je što pre pristupiti COSME programu i formirati kancelariju pri resornom Ministarstvu koja bi bila zadužena za sve informacije u vezi EU programa koji su dostupni RS za razvoj preduzetništva i inovacija.

\section{LITERATURA}

EEC. (1970). EEC industrial policy: Commission Memorandum COM (70) 100.

European Comission. (2005). Communication COM (2005) 474: Implementing the Community Lisbon Programme: A Policy Framework to Strengthen EU Manufacturing - towards a more integrated approach for Industrial Policy. Retrieved February 2, 2015, form http://ec.europa.eu/enterprise/policies/ sme/files/industry/com_2005/com_2005_474_en.pdf

European Comission. (2010a). EUROPA 2020: A strategy for smart, sustainable and inclusive growth, COM (2010). Brussels. 2020 final.

European Comission. (2010b). Communication COM (2010) 614: An Integrated Industrial Policy for the Globalisation Era. Putting Competitiveness and Sustainability at Centre Stage".

European Comission. (2003). COM (2003) 704 final: Some key issues in Europe's competitiveness - towards an integrated approach. Retrieved February 2, 2015, form http://ec.europa. eu/transparency/regdoc/rep/1/2003/EN/1-2003-704-ENF1-1.Pdf
European Comission. (2008). COM (2008) 394 final: A "Small Business Act" for Europe. Retrieved February 2, 2015, form http://eur-lex.europa.eu/LexUriServ/LexUriServ. do? uri=COM:2008:0394:FIN:EN:PDF

European Comission. (2010c). Communication COM (70)100: The Communitity's Industrial Policy: Commission Memorandum to the Council.

European Comission. (2011). Communication COM (2011)642: Industrial Policy: Reinforcing competitiveness.

European Comission. (2012). Communication COM (2012) 582 final: A Stronger European Industry for Growth and Economic Recovery.

European Comission. (2014). Communication COM (2014) 14/2: For a European Industrial Renaissance.

Evropska komisija. (2014). Izveštaj o napretku Srbije za 2014. godinu koji prati Saopštenje Komisije upućeno Evropskom parlamentu i Savetu, Strategija proširenja i ključni izazovi za 2014-2015. godinu, Evropska komisija, SWD (2014) 412, Brisel, 8.10.2014.

Evropski pokret u Srbiji. (2015). Vodič kroz strategiju: Evropa 2020. Beograd: Fond za otvoreno drušvo Srbija. Preuzeto 24.02.2105. sa http://www.mos.gov.rs/wp-content/uploads/ download-manager-files/EU\%202020.pdf

Filipović, S, \& Antevski, M. (2014). Pregovori Srbije i Evropske unije u vezi poglavlja 20 - preduzetništvo i industrijska politika, Evropsko zakonodavstvo br. 49/50. Beograd: Institut ua međunarodnu politiku i ekonomiju.

Kancelarija za evropske intetgracije. (2014). Nacionalni program za usvajanje pravnih tekovina Evropske unije (2014-2018). Preuzeto 24.02.2105. sa http://www.seio.gov.rs/upload/documents/nacionalna_dokumenta/npaa/npaa_2014_2018.pdf

Mićić, V. (2008). Industrijska politika Evropske unije. Ekonomski horizonti, 10(1-2), 45-70.

Ministarstvo privrede. (2014). Izveštaj o malim i srednjim preduzećima i preduzetništvu u 2013. Beograd: Ministrstvo privrede.

Ministarstvo privrede. (2014). Nacrt Strategije razvoja preduzetništva i konkurentnosti za period od 2014. do 2020. Godine. Preuzeto 24.02.2105. sa http://www.privreda.gov.rs/UserFiles/File/1_PRIVREDA/Nacrt-strategije-preduzetnistvokonkurentnost-9_6_2014.pdf

OECD. (2012). SME Policy Index:Western Balkansand Turkey 2012. Retrieved February 2, 2015, from http://www.oecd. org/investment/psd/SMEWBalkansTurkey.pdf

Rueda-Cantuche, J. M., Sousa, N., Andreoni, V., \& Arto, I. (2013). The Single Market as an Engine for Employment through External Trade. Jcms: Journal of Common Market Studies, 51(5), 931-947.

Sauter, W. (1977). Competition Law and Industrijal policy in the EU. Oxford, UK: Clarendon Press

Vlada Republike Srbije. (2011). Strategija i politika razvoja industrije Republike Srbije od 2011. do 2020. Godine. Preuzeto sa http://www.gs.gov.rs/lat/strategije-vs.html 